\title{
Profil Dehabilitasi Pasien Kusta di Rumah Sakit Kusta Alverno Singkawang: Studi Pendahuluan
}

\author{
Sri L. Menaldi, ${ }^{*}$ Valensia V. The, Inosensia D. Kusumo, \\ Melani Marissa \\ Departemen Dermatologi dan Venereologi, Fakultas Kedokteran Universitas Indonesia, \\ RSUPN Dr. Cipto Mangunkusumo, Jakarta
}

*korespondensi: susetyo_mr@yahoo.com

Diterima 28 November 2020; Diterima 21 April 2021

DOI: $10.23886 /$ ejki.9.24.

\begin{abstract}
Abstrak
Kusta dapat menyebabkan disabilitas permanen yang memengaruhi fisik dan psikis pasien. Stigma diri dan stigma sosial menyebabkan pasien mengalami dehabilitasi yang dapat menurunkan kualitas hidup penyandangnya. Penelitian ini merupakan studi pendahuluan yang bertujuan untuk mendapatkan profil dehabilitasi pasien kusta termasuk orang yang pernah mengalami kusta (OYPMK). Penelitian ini menggunakan metode potong lintang untuk menilai profil dehabilitasi pasien kusta dan OYPMK menggunakan skala dehabilitasi Anandaraj di RS Kusta Alverno Singkawang, bulan Juli 2019. Delapan puluh delapan subjek diikutkan dalam penelitian ini. Analisis data dilakukan menggunakan uji Mann Whitney untuk menilai hubungan tipe kusta dan derajat dehabilitasi, serta uji Kruskal Wallis untuk melihat hubungan antara reaksi kusta dan derajat disabilitas terhadap skala dehabilitasi. Analisis dilakukan menggunakan perangkat lunak SPSS for mac. Subjek terbanyak adalah laki-laki, usia produktif, bekerja sebagai petani, berpenghasilan kurang dari 1,5 juta per bulan, tidak bersekolah, sudah menikah, etnis Tionghoa, tinggal di dalam rumah yang padat, memiliki keluarga serumah yang menderita kusta, terdiagnosis kusta tipe multibasiler, pernah mengalami reaksi dan telah menyelesaikan pengobatan. Dari penelitian ini didapatkan bahwa tipe kusta dan disabilitas derajat nol dan dua berhubungan dengan skala dehabilitasi Anandaraj $(p<0.05)$. Stigma terhadap kusta hingga kini merupakan masalah yang belum dapat diatasi. Stigma dan disabilitas akibat kusta berperan penting terhadap kejadian dehabilitasi yang menyebabkan penurunan kualitas hidup pasien kusta dan OYPMK.

Kata kunci: Anandaraj, dehabilitasi, kusta, Singkawang.
\end{abstract}

\section{Dehabilitation Profile of Leprosy Patients in Alverno Singkawang Hospital: a Preliminary Study}

\begin{abstract}
Leprosy causes permanent disability that affects both physical and psychological aspect of the patient. Self-stigma and social stigma cause dehabilitation; therefore, reducing the quality of life of the patients. This research is a preliminary study to assess the dehabilitation profile of leprosy patients, including people who have had leprosy (OYPMK). A cross-sectional method was used to assess the dehabilitation scale of leprosy patients in Alverno Leprosy Hospital, Singkawang, using the Anandaraj dehabilitation scale. Eighty-eight subjects were included in the analysis. Mann-Whitney test was done to analyze the association between type of leprosy and dehabilitation scale, and Kruskal Wallis test was done to analyze the association between leprosy reaction and grade of disability with dehabilitation scale. Most subjects are male, productive age, farmers, less than 1.5 million wages per month, uneducated, married, Chinese ethnicity, living in a crowded house, had a family with leprosy, diagnosed with multibacillary leprosy, had an episode of leprosy reaction dan released from treatment. Type of leprosy and WHO disability grade 0 and 2 are related to the dehabilitation scale. Leprosy stigmatization is still a worrisome problem. Together with the disability, stigmatization affects the dehabilitation scale of leprosy patients leading to reduced quality of life.
\end{abstract}

Keywords: Anandaraj, dehabilitation, leprosy, Singkawang. 


\section{Pendahuluan}

Pasien kusta menderita secara fisik dan psikis sejak awal terdiagnosis; kemudian terlihat aspek sosial akibat stigma kusta yang sangat sulit dihilangkan. ${ }^{1}$ Anggapan bahwa kusta adalah penyakit kutukan, keturunan dan identik dengan cacat, sangat memengaruhi perilaku pasien dalam mencari pengobatan. Keterlambatan berobat atau ketidakteraturan berobat, menjadi salah satu penyebab disabilitas. Disabilitas pada tangan, kaki dan mata, menyebabkan pasien sulit melakukan kegiatan harian, bekerja atau bersekolah, menikah, bahkan tidak ingin melakukan kegiatan sosial..$^{1,2}$ Pasien disabilitas memerlukan dukungan untuk pemulihan fungsi, baik secara fisik maupun psikososial karena disabilitas tetap disandang walaupun pasien telah menyelesaikan pengobatan. ${ }^{3}$

Dehabilitasi merupakan istilah untuk kondisi seseorang yang kehilangan status sosialnya yang secara progresif terisolasi dari keluarga dan teman. ${ }^{4}$ Pada kusta, disabilitas dan stigma terkait kusta berperan terhadap kejadian dehabilitasi. Pengaruh dehabilitasi pada kehidupan seharihari dapat diukur menggunakan skala dehabilitasi Anandaraj. Skala tersebut menilai 4 aspek penting dalam kehidupan, yaitu hubungan dengan keluarga, pekerjaan, interaksi sosial dan kepercayaan diri. ${ }^{5}$ Instrumen dikembangkan dan digunakan untuk menilai dampak negatif stigma kusta dalam kehidupan pasien. ${ }^{5,6}$

Kelompok dokter peduli kusta, terdiri atas dokter spesialis kulit, mata dan rehabilitasi medik Fakultas Kedokteran Universitas Indonesia Rumah Sakit Umum Pusat Nasional dr. Cipto Mangunkusumo (RSCM) Jakarta yang tergabung dalam "KATAMATAKU" (Identifikasi Tanda-Tanda Mata, Ekstremitas, dan Kulit pada Penderita Kusta) melakukan Program Pengabdian Masyarakat di RS Kusta Alverno Singkawang. Penelitian ini adalah bagian dari program tersebut, dan merupakan studi pendahuluan yang bertujuan untuk mendapatkan profil dehabilitasi pasien kusta dan orang yang pernah mengalami kusta (OYPMK).

\section{Metode}

Penelitian ini menggunakan rancangan potong lintang dengan subjek penelitian semua pasien kusta dan OYPMK atau telah menyelesaikan pengobatan, berusia $>15$ tahun, berobat ke RS Kusta Alverno, Singkawang, saat diadakan
Program Pengabdian Masyarakat, Juli 2019. Program dilaksanakan oleh tim "KATAMATAKU" bekerja sama dengan Perhimpunan Dokter Spesialis Kulit dan Kelamin (PERDOSKI) Cabang Pontianak. Penelitian ini telah mendapat izin etik dari Fakultas Kedokteran Universitas Indonesia nomor KET-698/UN2.F1/ETIK/PPM.00.02/ 2019.

Sebanyak 99 pasien kusta dari sekitar kota Singkawang berkunjung ke RS Kusta Alverno, untuk mendapatkan pelayanan terkait penyakit kusta, termasuk disabilitas tangan dan kaki serta mata. Terdapat satu pasien anak dan 10 pasien yang tidak mengisi data diri dengan lengkap, sehingga tidak diikutsertakan dalam analisis. Dengan demikian, 88 pasien digunakan sebagai subjek dan menandatangani formulir persetujuan mengikuti penelitian. Pemeriksaan klinis dan penentuan derajat disabilitas menurut $\mathrm{WHO}$ dilakukan pada semua subjek. Selanjutnya subjek mengisi kuesioner skala dehabilitasi Anandaraj didampingi dokter pemeriksa karena kuesioner dehabilitasi berbahasa Indonesia belum tersedia.

Skala dehabilitasi Anandaraj adalah skala kuantitatif terdiri atas 52 butir pertanyaan mencakup 4 bahasan utama, yaitu hubungan dengan keluarga, kondisi pekerjaan, interaksi sosial dan kepercayaan diri. ${ }^{5}$ Sebanyak 45 pertanyaan menggunakan skala Likert dan 7 pertanyaan dengan jawaban ya atau tidak. Rentang nilai skor 24-97. Skor $<75$ berarti skala dehabilitasi tinggi, skor $76-86$ sedang, dan skor $>86$ rendah. Semakin tinggi skala dehabilitasi (skor 75 atau kurang), semakin besar dampak kusta dalam kehidupan subjek. Derajat disabilitas, tipe kusta saat awal terdiagnosis dan riwayat reaksi kusta dihubungkan dengan skala dehabilitasi Anandaraj dan dianalisis dengan SPSS for Mac. Data dianalisis menggunakan uji Mann-Whitney dan uji Kruskal Wallis.

\section{Hasil}

Data demografi subjek ditampilkan pada Tabel 1. Sebagian besar subjek adalah laki-laki berusia 15-60 tahun. Pendidikan subjek terbanyak ialah tamat sekolah dasar dan tidak bersekolah. Umumnya subjek bekerja sebagai petani. Penghasilan subjek terbanyak kurang dari 1,5 juta rupiah per bulan. Sekitar $68,2 \%$ subjek telah menikah dan kebanyakan dari suku Tionghoa. Sebanyak 54 subjek $(61,4 \%)$ memiliki keluarga serumah yang menderita kusta. 
Tabel 1. Karakteristik Demografi Subjek di RS Kusta Alverno, Singkawang

\begin{tabular}{|c|c|c|}
\hline Karakteristik & $\begin{array}{l}\text { Frekuensi } \\
\quad(n=88)\end{array}$ & $\%$ \\
\hline \multicolumn{3}{|l|}{ Jenis Kelamin } \\
\hline Laki-laki & 59 & 67 \\
\hline Perempuan & 29 & 33 \\
\hline \multicolumn{3}{|l|}{ Usia } \\
\hline $15-60$ tahun & 55 & 35,3 \\
\hline$>60$ tahun & 31 & 19,9 \\
\hline Tidak menjawab & 2 & 1,3 \\
\hline \multicolumn{3}{|l|}{ Pendidikan } \\
\hline Perguruan tinggi & 3 & 3,4 \\
\hline Sekolah menengah & 16 & 18,2 \\
\hline Sekolah dasar & 31 & 35,2 \\
\hline Tidak sekolah & 38 & 43,2 \\
\hline \multicolumn{3}{|l|}{ Pekerjaan } \\
\hline Pelajar & 2 & 2,3 \\
\hline Buruh & 4 & 4,5 \\
\hline Guru & 1 & 1,1 \\
\hline Petani & 44 & 50,0 \\
\hline Tidak bekerja & 31 & 35,2 \\
\hline Lainnya & 6 & 6,8 \\
\hline \multicolumn{3}{|l|}{ Penghasilan } \\
\hline$<1,5$ juta & 56 & 63,6 \\
\hline $1,5-3,5$ juta & 6 & 6,8 \\
\hline$>3,5$ juta & 1 & 1,1 \\
\hline Tidak menjawab & 25 & 28,4 \\
\hline \multicolumn{3}{|l|}{ Status pernikahan } \\
\hline Menikah & 60 & 68,2 \\
\hline Belum menikah & 22 & 25 \\
\hline Cerai & 5 & 5,7 \\
\hline Tidak menjawab & 1 & 1,1 \\
\hline \multicolumn{3}{|l|}{ Suku } \\
\hline Tionghoa & 29 & 33 \\
\hline Jawa & 15 & 17 \\
\hline Madura & 13 & 14,8 \\
\hline Melayu & 12 & 13,6 \\
\hline Dayak & 9 & 10,2 \\
\hline Nusa Tenggara & 4 & 4,5 \\
\hline Lainnya & 3 & 3,4 \\
\hline Tidak menjawab & 3 & 3,4 \\
\hline \multicolumn{3}{|c|}{ Jumlah penderita kusta serumah } \\
\hline Tidak ada & 34 & 38,6 \\
\hline 1 orang & 38 & 43,2 \\
\hline 2 orang & 13 & 14,8 \\
\hline$>2$ orang & 3 & 3,4 \\
\hline
\end{tabular}

Tabel 2. menunjukkan tipe kusta terbanyak ialah tipe multibasiler (MB). Subjek yang mengalami reaksi kusta tipe satu (reaksi reversal) maupun ENL sama banyak dan sebagian besar pasien telah menyelesaikan pengobatan.

Tabel 2. Profil Kusta Subjek di RS Alverno Singkawang

\begin{tabular}{lcc}
\hline Profil Kusta & $\begin{array}{c}\text { Frekuensi } \\
(\mathbf{n}=\mathbf{8 8})\end{array}$ & $\%$ \\
\hline Tipe kusta saat pertama & & \\
diagnosis ditegakkan & & \\
$\quad$ Pausibasiler & 22 & 25,0 \\
$\quad$ Multibasiler & 53 & 60,2 \\
$\quad$ Tidak tahu & 13 & 14,8 \\
Riwayat reaksi kusta & 35 & 39,8 \\
$\quad$ Tidak mengalami reaksi & 21 & 23,9 \\
Tipe 1 & 21 & 23,9 \\
Tipe 2 & 5 & 5,7 \\
$\quad$ Reaksi tipe 1 dan 2 & 6 & 6,8 \\
Tidak tahu & & \\
Status pengobatan kusta & 5 & 5,7 \\
MDT-PB & 8 & 9,1 \\
MDT-MB & 71 & 80,7 \\
Release from treatment & 4 & 4,5 \\
Tidak tahu & &
\end{tabular}

Pada pemeriksaan klinis ditemukan disabilitas derajat 2 pada 38 dari $88(43,18 \%)$ subjek dan satu subjek dapat memiliki lebih dari satu macam disabilitas. Pemendekan jari tangan merupakan disabilitas terbanyak (Tabel 3).

Tabel 3. Jenis Disabilitas Derajat 2 pada Subjek di RS Kusta Alverno, Singkawang

\begin{tabular}{lcc}
\hline Jenis Disabilitas & $\mathbf{n}$ & \% \\
\hline Pemendekan jari tangan & 27 & 71,05 \\
Clawhand (kiting jari tangan) & 25 & 65,79 \\
Pemendekan jari kaki & 20 & 52,63 \\
Ulkus pada kaki & 16 & 42,11 \\
Clawtoes (kiting jari kaki) & 15 & 39,47 \\
Atrofi otot tangan & 14 & 36,84 \\
Atrofi otot kaki & 9 & 23,68 \\
Lagoftalmos & 9 & 23,68 \\
Drop foot & 7 & 18,42 \\
Drophand & 6 & 15,79 \\
Ulkus pada tangan & 6 & 15,79 \\
Amputasi di kaki & 6 & 15,79 \\
\hline
\end{tabular}


Skala Anandaraj menunjukkan skala rendah pada 39 subjek (44,3\%), skala sedang 29 subjek (33\%), dan tinggi pada 20 subjek (22,7\%). Sebagian besar subjek saat pertama kali terdiagnosis merupakan kusta tipe MB. Terdapat 13 subjek yang tidak mengetahui tipe kusta yang dialami, sehingga analisis selanjutnya hanya dilakukan pada 75 subjek. Tipe kusta berhubungan dengan skala dehabilitasi Anandaraj (uji Mann-Whitney, $p=0,037^{*}$ ).

Tabel 4. Hubungan Tipe Kusta, Reaksi Kusta dan Derajat Disabilitas dengan Skala Dehabilitasi Anandaraj

\begin{tabular}{|c|c|c|c|c|}
\hline \multirow[b]{2}{*}{$\begin{array}{c}\text { Rendah } \\
\text { Skor >86 } \\
\text { n (\%) }\end{array}$} & \multicolumn{3}{|c|}{ Skala Dehabilitasi Anandaraj } & \multirow[t]{2}{*}{ Jumlah } \\
\hline & $\begin{array}{c}\text { Sedang } \\
\text { Skor 76-86 } \\
\text { n(\%) }\end{array}$ & $\begin{array}{c}\text { Tinggi } \\
<75 \\
\mathrm{n}(\%) \\
\end{array}$ & $\mathrm{n}(\%)$ & \\
\hline \multicolumn{5}{|l|}{ Tipe Kusta } \\
\hline Pausibasiler & $5(14,3)$ & $14(48,3)$ & $3(27,3)$ & $22(29,3)$ \\
\hline Multibasiler & $30(85,7)$ & $15(51,7)$ & $8(72,7)$ & $53(70,7)$ \\
\hline \multicolumn{5}{|l|}{ Reaksi Kusta } \\
\hline Tidak ada & $11(29,7)$ & $14(51,9)$ & $10(55,6)$ & $35(42,7)$ \\
\hline Tipe 1 & $9(24,3)$ & $8(29,6)$ & $4(22,2)$ & $21(25,6)$ \\
\hline Tipe 2 & $14(37,8)$ & $4(14,8)$ & $3(16,7)$ & $21(25,6)$ \\
\hline Tipe 1 dan 2 & $3(8,1)$ & $1(3,7)$ & $1(5,6)$ & $5(6,1)$ \\
\hline \multicolumn{5}{|l|}{ Derajat Disabilitas } \\
\hline 0 & $22(56,4)$ & $12(41,4)$ & $4(20)$ & $38(43,2)$ \\
\hline 1 & $8(20,5)$ & $1(3,4)$ & $3(15)$ & $12(13,6)$ \\
\hline 2 & $9(23,1)$ & $16(55,2)$ & $13(65)$ & $38(43,2)$ \\
\hline
\end{tabular}

Pada penelitian ini didapatkan 47 subjek yang memiliki riwayat reaksi kusta, 35 subjek tidak mengalami reaksi, dan 6 subjek tidak mengetahui riwayat reaksi yang dialaminya, sehingga yang dianalisis adalah 82 subjek. Pada uji Kruskal Wallis, diperoleh nilai $p=0,115$ yang berarti reaksi kusta tidak berhubungan dengan skala dehabilitasi (Tabel 4).

Tabel 4 juga menunjukkan derajat disabilitas berhubungan dengan skala dehabilitasi Anandaraj berdasarkan uji Kruskal Wallis $(p=0,003)$. Analisis dilanjutkan dengan pairwise comparison menggunakan Bonferoni correction dan didapatkan perbedaan proporsi antara skala dehabilitasi Anandaraj yang rendah dengan derajat disabilitas 0 dan 2 .

\section{Diskusi}

Pasien kusta yang berkunjung ke RS Kusta Alverno Singkawang sebagian besar adalah lakilaki. Data ini sesuai dengan penelitian terdahulu, bahwa pasien kusta laki-laki umumnya lebih banyak dibandingkan perempuan (2:1);-10 diduga karena laki-laki lebih banyak berada di luar rumah dan kemungkinan terpapar kusta lebih besar.

Pasien kusta umumnya berusia $20-40$ tahun atau dewasa muda. ${ }^{7,8}$ Pada penelitian ini, usia subjek terutama 15-60 tahun dan terdapat
$19,9 \%$ berusia $>60$ tahun. Bila dilihat dari riwayat pengobatan, $80,7 \%$ subjek adalah OYPMK yang telah menyelesaikan pengobatan bertahun-tahun yang lalu. Umumnya mereka mengalami sakit kusta pada saat berusia muda dan tetap berkunjung ke rumah sakit terkait disabilitas yang disandangnya.

Data demografis penelitian ini menunjukkan pasien kusta sebagian besar adalah etnis Tionghoa. Mengacu pada data Badan Pusat Statistik (BPS) tahun 2011, penduduk di Kota Singkawang terbanyak berasal dari etnis Tionghoa, sedangkan suku lainnya merupakan pendatang atau transmigran, seperti suku Jawa, Madura, Melayu dan Nusa Tenggara. ${ }^{11}$ Selain itu, etnis Tionghoa memiliki kecenderungan mudah menderita kusta, kemungkinan terkait dengan genotip HLA-DRB1/ DQA1 sebagai major leprosy susceptibility genes yang terdapat pada etnis tersebut. ${ }^{8,12}$ Pasien kusta yang berasal dari suku Jawa dan Madura menempati urutan kedua dan ketiga terbanyak. Hal tersebut dapat dihubungkan dengan banyaknya kasus kusta di Jawa Timur sebagai daerah asal mereka. Hingga tahun 2015-2016, Jawa Timur merupakan satusatunya provinsi di Indonesia bagian barat yang memiliki angka beban kusta yang tinggi, dengan kasus baru terbanyak pada tahun $2017 . .^{13}$ 
Penelitian ini tidak berbeda dengan penelitian Abdela, ${ }^{10}$ yaitu sebagian besar subjek tidak bersekolah, memiliki status menikah dan bekerja sebagai petani. Pada penelitian ini yang dimaksud dengan tidak bersekolah ialah tidak mengikuti sekolah formal atau tidak tamat sekolah dasar karena mereka malu dan takut pergi ke sekolah terkait stigma. Terdapat subjek berusia lanjut yang buta huruf dan tidak dapat berbahasa Indonesia sehingga pendampingan subjek sangat penting pada saat pengisian kuesioner. Seshadri et al ${ }^{6}$ juga memberikan pendampingan pada subjek buta huruf.

Pekerjaan sebagai petaniatau buruh merupakan pekerjaan terbanyak pada penelitian ini. Menjadi petani atau buruh merupakan pilihan pekerjaan yang dapat dilakukan, terkait rendahnya pendidikan dan keterbatasan keterampilan. Penelitian ini sejalan dengan penelitian oleh Muchtar et al ${ }^{16} \mathrm{di}$ RS Wahidin Sudiro Husodo Makassar yang mendapatkan 57,5\% pekerjaan pasien kusta adalah petani. Sementara itu Nabila et al, ${ }^{17}$ melaporkan pekerjaan terbanyak pasien kusta di Rumah Sakit Kusta Kediri adalah swasta $(43,33 \%)$ diikuti pekerjaan sebagai petani $(25,83 \%)$. Perbedaan itu disebabkan wilayah tempat tinggal pasien adalah perkotaan dan industri. Selain itu, kesempatan mendapat pekerjaan yang layak juga tidak mudah. Pasien kusta dan OYPMK seringkali ditolak bekerja, karena stigma sosial di masyarakat antara lain takut tertular kusta. ${ }^{14,15}$

Jumlah anggota keluarga yang tinggal serumah yang juga menderita kusta lebih dari satu orang yaitu mencapai $61,4 \%$. Beberapa pasien kusta menikah dengan pasien kusta lainnya dan pada umumnya berada di komunitas kusta. Kondisi tersebut menyebabkan peningkatan kasus karena penularan akibat kontak lama dan erat. Hasil penelitian ini sejalan dengan penelitian Teixeira et $a{ }^{18}$ yang mendapatkan 97,3\% kasus kusta diperoleh dari kontak serumah, terutama dengan kusta tipe MB.

Tipe kusta terbanyak pada penelitian ini ialah $M B$, tidak berbeda dengan penelitian Nabila et al ${ }^{17}$ di Rumah Sakit Kusta Kediri, yang mendapatkan $91,76 \%$ pasien adalah tipe MB. Data penelitian dari berbagai negara juga melaporkan bahwa tipe MB merupakan kasus terbanyak. . $^{10,19,20}$ Selain sebagai sumber penularan karena memiliki jumlah basil yang banyak, tipe MB juga memiliki risiko lebih tinggi terjadinya disabilitas. ${ }^{21}$ Penelitian de Paula et al, ${ }^{20}$ mendapatkan tipe MB empat kali lebih besar untuk mengalami disabilitas fisik dibandingkan tipe PB.

Pada penelitian ini, 47 dari 88 (53,41\%) subjek mengalami reaksi, baik reaksi reversal maupun eritema nodosum leprosum (ENL).
Berbagai penelitian melaporkan kejadian reaksi kusta berkisar 20 hingga 43\%. ${ }^{10,17}$ Reaksi kusta merupakan faktor risiko disabilitas jika tidak ditangani dengan baik. Disabilitas menyebabkan stigma semakin sulit untuk dihilangkan. De Paula et $\mathrm{al}^{20}$ menyarankan target intervensi diutamakan pada pasien kusta yang mengalami reaksi, karena berisiko terjadi disabilitas.

Pada penelitian ini, terdapat perbedaan bermakna antara tipe kusta dengan skala dehabilitasi. Hal yang menarik adalah tipe MB merupakan kelompok terbesar dengan skala dehabilitasi rendah, yang berarti dampak negatif kusta relatif kecil. Kondisi tersebut mungkin karena sebagian besar subjek sudah lama berada di komunitas kusta sehingga saling memahami dan dapat beradaptasi dengan disabilitas maupun stigma. Sebaliknya Seshadri et $\mathrm{al}^{6}$ melaporkan bahwa tipe kusta tidak berhubungan dengan skala dehabilitasi, mungkin karena kondisi demografis berbeda dengan penelitian ini. Reaksi kusta dapat menimbulkan disabilitas akibat neuritis yang tidak tertangani dengan baik, namun pada penelitian ini reaksi kusta tidak berhubungan dengan skala dehabilitasi. Selain itu tidak diperoleh data lebih rinci keterkaitan disabilitas akibat reaksi karena reaksi terjadi bertahun-tahun yang lalu. Seshadri et al ${ }^{6}$ mendapatkan bahwa reaksi kusta merupakan prekursor disabilitas namun, tidak dikaitkan dengan dehabilitasi.

Disabilitas derajat 2 pada penelitian ini lebih banyak dibandingkan derajat 1 . Hasil tersebut tidak berbeda dengan penelitian Guthi et $\mathrm{al}^{3}$ yang mendapatkan disabilitas derajat 2 lebih banyak. Pasien dengan disabilitas derajat 2 relatif memiliki skala dehabilitasi lebih tinggi dibandingkan dengan yang tidak memiliki disabilitas. Disabilitas derajat 2 merupakan disabilitas yang langsung terlihat, sehingga stigma dari masyarakat termasuk orang terdekat seperti teman dan keluarga juga semakin besar. Selain stigma, disabilitas menyebabkan pasien mengalami keterbatasan fisik untuk bekerja dan melakukan aktivitas sehari-hari. ${ }^{21}$ Kedua hal tersebut berkontribusi besar terhadap kejadian dehabilitasi pasien kusta termasuk OYPMK. Temuan ini sesuai dengan penelitian van Brakel et $a^{14}$ yang membahas bahwa pasien kusta yang mengalami disabilitas lebih berat dan keterbatasan aktivitas, akan memengaruhi partisipasinya di berbagai kegiatan, termasuk kegiatan sosial.

Penelitian ini memiliki keterbatasan, yaitu penggunaan kuesioner yang belum diterjemahkan dalam Bahasa Indonesia, sehingga pengisiannya perlu pendampingan. Analisis kualitatif untuk memperkuat hasil kuantitatif tidak dilakukan. Selain itu, mayoritas subjek tinggal di sekitar pemukiman kusta, sehingga 
memiliki karakteristik sosiodemografi yang mirip dan tidak dapat menggambarkan kondisi populasi secara umum.

\section{Kesimpulan}

Dehabilitasi pada pasien kusta berhubungan dengan tipe kusta dan disabilitas derajat 2 yang jelas terlihat. Pencegahan disabilitas harus dilakukan sejak dini agar tidak terjadi cacat dan cacat tidak berlanjut menjadi lebih berat. Disabilitas yang terlihat akan menyebabkan stigma terhadap kusta sulit dihilangkan dan mengakibatkan dehabilitasi penyandangnya. Perlu dilakukan kerja sama yang terintegrasi dengan berbagai disiplin ilmu seperti rehabilitasi medik, ilmu budaya, psikologi dan ilmu lain yang terkait untuk menyelesaikan masalah stigma dan dehabilitasi akibat kusta. Dengan demikian kualitas hidup pasien kusta dan OYPMK dapat diperbaiki.

\section{Ucapan Terima Kasih}

Peneliti mengucapkan terima kasih kepada dr. Barita P. Ompusunggu, MKM, Direktur Rumah Sakit Kusta Alverno Singkawang; dr Teguh Alyansyah SpKK, Ketua Panitia Bakti Sosial; dr Yuliana Teguh, SpKK, Ketua PERDOSKI Cabang Pontianak; dokter spesialis kulit dan kelamin di Kalimantan Barat, serta semua pihak yang membantu penelitian ini.

\section{Daftar Pustaka}

1. Gopal PK. Psychosocial aspects in leprosy. Dalam: Kumar B, Kar HK, editor. IAL Textbook of leprosy. Edisi ke-2. New Delhi: Jaypee Brothers Medical Publishers Ltd. 2016.h.641-5.

2. Dongre VV. Human rights and stigma in leprosy. Dalam: Kumar B, Kar HK, editor. IAL Textbook of leprosy. Edisi ke-2. New Delhi: Jaypee Brothers Medical Publishers Ltd 2016.h.646-51.

3. Guthi VR, Sreedevi A. Study on disability limitation, rehabilitation and social needs of persons affected by leprosy in Kurnool division of Kurnool district. Int J Community Med Public Health. 2018;8:3526-31.

4. Srinivasan H. Consequences of leprosy. Dalam: Prevention of disabilities in patients with leprosy. A practical guide. Geneva: World Health Organization; 1993.

5. Anandaraj H. Measurement of dehabilitation in patients of leprosy - a scale. Indian J Lepr. 1995;153-60.

6. Seshadri D, Khaitan BK, Khanna N, Sagar R. Dehabilitation in era of elimination and rehabilitation: a study of 100 leprosy patients from a tertiary care hospital in India. Lepr Rev. 2015;86:62-74.

7. Brycesson A, Pfaltzgraff RE. Epidemiology. Dalam: Leprosy. Edisi ke-3. Edinburgh: Churchill Livingstone; 1990.h.203-16.

8. Joshi PL. Epidemiology of leprosy. Dalam: Kumar B, Kar HK, editor. IAL Textbook of Leprosy. Edisi ke-2. New Delhi:
Jaypee Brothers Medical Publishers Ltd.; 2016.h.31-44.

9. Noordende AT, Korfage IJ, Lisam S, Arif MA, Kumar $A$, van Brakel $\mathrm{WH}$. The role of perceptions and knowledge of leprosy in the elimination of leprosy: a baseline study in Fatehpur district, northern India. PLoS Negl Trop Dis. 2019;13:e0007302

10. Abdela SG, Henten S, Abegaz SH, Bayuh FB, Zawdu FT, Berhe FT. Activity limitation and social participation restriction among leprosy patients in Boru Meda Hospital, Amhara Region, Ethiopia. PLoS Negl Trop Dis. 2020;14:e0008702

11. Badan Pusat Statistik Kota Singkawang. Statistik Daerah Kota Singkawang. Diunduh dari https:// singkawangkota.bps.go.id/publication/2020/09/18/01

12. d26783e564b58bceabc3f1/statistik-daerah-kotasingkawang-2020.html.

13. Rani R. Immunogenetics of leprosy. Dalam: Kumar B, Kar HK, editor. IAL Textbook of leprosy. Edisi ke-2. New Delhi: Jaypee Brothers Medical Publishers Ltd.; 2016.h.73-89.

14. Pusat data dan informasi Kementerian Kesehatan RI. Hapuskan stigma dan diskriminasi terhadap kusta. 2018. Diunduh dari https://pusdatin.kemkes.go.id/ article/view/18053000001/infodatin-kusta-2018.html.

15. van Brakel $W H$, Sihombing $B$, Djarir $H$, Beise $K$, Kusumawardhani L, Yulihane $\mathrm{R}$ et al. Disability in people affected by leprosy: the role of impairment, activity, social participation, stigma and discrimination. Global Health Action. 2012;5:1-11.

16. Kaehler N, Adhikar B, Raut S, Marahatta SB, Chapman RS. Perceived stigma towards leprosy among community members living close to Nonsomboon Leprosy Colony in Thailand. PLOS ONE|DOI: 10.1371/ journal.pone.0129086. Juni 5,2015

17. Muchtar SV, Amiruddin MD, Yosi Y. Lepromin test pada penderita kusta. Berkala IImu Kesehatan Kulit dan Kelamin. 2009;21:18-24.

18. Nabila AQ, Nurainiwati SA, Handaja D. Profil penderita penyakit kusta di Rumah Sakit Kusta Kediri periode Januari 2010 sampai Desember 2010. UMM Scientific Journals. 2012;8:70-7.

19. Teixeira CSS, Pescarini JM, Alves FJO. Incidence of and factors associated with leprosy among household contacts of patients with leprosy in Brazil. JAMA Dermatol. 2020;156:640-48.

20. Leon KE, Jacob JT, Paredes CF, Kozarsky PE, Wu HM, Fairley JK. Delayed diagnosis, leprosy reactions, and nerve injury among individuals with Hansen's disease seen at a United States clinic. Open Forum Infectious Diseases. 2016. DOI: 10.1093/ofid/ofw063

21. de Paula HL, Carlos DFS, Silva SR. Risk factors for physical disability in patients with leprosy. JAMA Dermatol. 2019;155:1120-8.

22. Slim FJ, van Schie $\mathrm{CH}$, Keukenkamp R, Faber WR, Nollet F. Effects of impairments on activities and participation in people affected by leprosy in Netherlands. J Rehabil Med. 2010;42:536-43. 